\title{
$3^{\text {rd }}$ International Conference On Advanced Research in EDUCATION
}

11-14 March, $2021 \quad$ Oxford - United Kingdom

\section{Drama Education Through Storytelling Strategy Develops Students' Critical Thinking Skills}

\author{
Aikaterini Dima ${ }^{1}$, Elena Kaiafa ${ }^{2}$ and Asterios Tsiaras ${ }^{3}$ \\ ${ }^{1,2} \mathrm{PhD}$ Student, Department of Theatre Studies, Faculty of Fine Arts, University of Peloponnese, \\ Nafplio, Greece \\ ${ }^{3}$ Professor, Department of Theatre Studies, Faculty of Fine Arts, University of Peloponnese, Nafplio, \\ Greece
}

\begin{abstract}
The present study focuses on an innovative intervention programme based on drama education and its tools including storytelling, aiming at the cultivation of critical thinking skills of primary school students in a playful and enjoyable mode. Educating students to think critically is paramount both for the students themselves and society at large. Students being the citizens of tomorrow should be free from any prejudice and potential misinformation and develop a critical view of things. At the same time, the experience of drama education has taught us that it can affect children's judgment as well as the way they perceive the world surrounding them. The study has been carried out during the period of 2020-21 and has been based on the methodology of experimental research with pre-test and post-test evaluation, in order to identify the contribution of drama education in the development of primary school students' five critical thinking skills. The selection of primary schools in Greece was completed by random sampling and included 400 students aged 8-10 years. During the research period, 12 innovative interventions were implemented based on the narration and dramatization of fairy tales and stories. The multimodal approach with respect to the selection of research tools was applied and the research was completed by triangulating the quantitative and qualitative data collected. The results of the research provided evidence according to which an intervention programme based on drama education and its tools can develop the critical thinking skills of primary school students.
\end{abstract}

Keywords: Critical thinking skills, Drama education, Experimental research Innovative intervention programme, Storytelling 


\section{$3^{\text {rd }}$ International Conference On Advanced Research in EDUCATION}

\section{Introduction}

Thought comprises the basis of all the cognitive processes of the brain that are involved in processing of information, formation of concepts, problem solving and decision making. Thought is logic and logic in turn is a chain of simple ideas associated with the application of strict rules (McGregor, 2007). Critical thinking describes not only the student's ability to think according to the rules of logic, but also their ability to apply these skills to the problems they encounter in real life. Thinking critically in its strong sense, according to Paul and Elder (2012), requires development at the same time of a sense of justice, in order to cultivate the basic skills of critical thinking and, therefore, start thinking correctly. Students, after all, are not passive but active recipients while practicing critical thinking.

Development of critical thinking is considered as a widely accepted educational goal since it prepares students for succeeding in life, respects students' autonomy and trains them to be fair and open-minded. Dewey (1997) believes that the training of critical thinking skills is of great value both to the individual and society itself.

Experience in drama education can significantly contribute to the shaping of attitudes and development of ways of thinking. According to Fisher (2001), drama education and its tools such as storytelling, play an important role in enhancing students' critical thinking ability since it can link thinking skills to behaviour.

Franks (2019) argues that learning and drama are a holistic experience since body and mind harmonize, emotions and thought work together to represent real life situations and lead to meaningful decisions.

One of the most effective way for children to engage in drama education is through stories or fairytales because through this approach students have the opportunity to discover issues that emerge from stories creatively and not just from a simple class discussion (Winston \& Tandy, 2009).

In light of the above, an attempt was made to investigate whether the theatrical techniques of drama education and in particular storytelling can contribute to the development of the critical thinking skills of primary school students.

\subsection{Critical thinking skills}

Critical thinking is defined as a cognitive activity related to the use of the mind (Padmanabha, 2018). According to Dewey (1997), human thought is the natural tendency of the mind. Dewey even characterised critical thinking as a persistent, active, and diligent process of examining a belief or a supposed form of knowledge in the light of the reasons it supports and the further conclusions to which it tends (Dewey, 1910 . Jiang, 2017). Facione (1990) defined it as a deliberate decision, which guides individuals in understanding, researching, evaluating and drawing of conclusions. Ennis (1993) characterised it as a meditative and rational process that focuses on the decision of what to believe in or the action to be taken (Fisher, 2001). Eales-Reynolds et al. (2013), much later, delineate critical thinking as a synergy between reflection and in-depth exploration of ideas and concepts, including awareness, personal prejudice, and experience. 


\section{$3^{\text {rd }}$ International Conference On Advanced Research in EDUCATION}

Critical thinking synthesis consists of a set of collective, cognitive and metacognitive skills as well as cognitive attitudes and dispositions (Matsagouras, 2001). Therefore, it is a unidimensional process of the mind. Critical thinking skills that can be measured and assessed include abstract and inductive thinking, observation, reliability, and problem solving (Ennis, 1993; Starkey, 2010). A brief explanation follows.

Abstraction begins with a general statement or hypothesis and examines the possibilities to reach a specific, logical conclusion (Starkey, 2010). It is a kind of reasoning, directed from the general to the specific (individual) where a conclusion necessarily arises from the cited arguments or the respective assumptions made.

Induction functions in the opposite way of abstraction. The inductive thinking process is often referred to as generalisation because it commences with specific details or facts and proceeds to a general conclusion (Hacker, 2006). Specifically, the process of inductive reasoning development starts with specific observations and measures, identification of patterns and regularities, formulation of some temporary hypotheses that can be investigated and tested and eventually ending up to drawing some general conclusions and/or theories (Trochim, 2020).

Observation which comprises another skill of critical thinking, is essentially a series of activities for collecting data with respect to an object, using all the senses (Karamustafaoğlu, 2011). The ability to observe and gather information about the world is important because it forms the basis of good communication.

One of the skills of critical thinking is the ability to evaluate a source of information and identify it as either true or false. Therefore, the skill of reliability exists when the student can evaluate and ensure the reliability of a particular data source and this in turn can lead to the specification of the correct solution to a problem that arises (Dima et al., 2020).

The term troubleshooting and resolution is used to explain a situation that needs to be properly assessed and addressed. Problems arise knowingly or unknowingly and seek a solution (Hsieh et al., 2007). According to Dostal (2014) as a problem is pointed out a condition in which the individual faces a practical or theoretical difficulty and is led through it to the enrichment of their knowledge. In order for an individual to solve a problem, a series of mental processes must be applied, such as understanding the problem, constructing and implementing a solution plan and realising the functional and non-functional actions (Chadwick, 2014).

Educating students to be able to use abstract and inductive thinking effectively, to observe thoroughly, to check the reliability of information sources, to identify and solve any problems that arise, makes them critical people and promotes them to be the hope of the world for the future.

\subsection{The role of drama education in today's student's life.}

The first reference to drama education is found in the time of Plato, when he mentions in The Republic "let your children's lessons take the form of play" (Bolton, 2007, p.45). 


\section{$3^{\text {rd }}$ International Conference On Advanced Research in EDUCATION}

From the ancient times and over the following centuries until today drama education has evolved and has been introduced in the educational planning schemes of many countries around the world. Educational progress initiated in the beginning of 20th century. Around 1920 the need of people to create a healthy society began to emerge, starting with the development of children, pedagogy and the cultivation of democracy, introducing drama to schools' curricula (Sweeney, 1936).

According to Winston and Tandy (2009) drama education is playful and uses stories in order to explore issues of human import. Nevertheless, why is drama necessary to exist in the education and school life of students? Teachers and scholars agree that drama education needs to be included in educational programmes since it cultivates children's mental development as well as their democratic values (Gallagher et al., 2017). Students work in groups harmoniously with each other, learning thus to cooperate and be prepared for the respective requirements in their real social life (Winship, 2009). Through teamwork children build experiences based on real life and develop a sense of 'belongingness', 'trust' and 'security' which are cultivated in the secure environment created by drama (Mreiwed et al., 2017). Furthermore, Cook (1917) argued that students gain empathy by approaching texts and characters through the techniques of drama.

One of the most important representatives of drama education is Dorothy Heathcote who allowed children to decide what, when or what they want, letting them to be free in the action space in order to avoid the "group inertia". In this way she helped children, "use drama to expand their awareness enabling them to look at reality through fantasy" (Heathcote \& Wagner, 1976, p.15). Also, O 'Neil and Lambert (1976) in Drama Guidelines argue that drama teaching can be very effective with students because of its nature, namely by putting them in situations which occur in the everyday life they may understand others and themselves as a result. This active involvement of students renders drama a strong social subject. in addition, Doyle (1993) lists some of the benefits of drama education including: the ability to develop awareness of rhythm, time, the ability to follow sound and remember it, also to move body rhythmically and sequentially as well as to synchronize movements. Doyle (1993) points out that through drama new words and phrases can be learned and thus vocabulary can be enriched.

Drama is therefore a means to practice these skills without having to possess them from the beginning as a prerequisite to participate in it. Drama, after all, is a subject that promotes a collaborative approach to learning, reaffirming Vygotsky's belief that students learn more effectively and efficiently if they work together rather than individually (Rieber, \& Robinson, 2004).

\subsection{Drama Education: The Storytelling Convention}

In the context of the present study, the focus of the respective research has been chosen to be on one strategy that drama uses: Storytelling. National Council of Teacher of English (1992, p.5) define storytelling as "relating a tale to one or more listeners through voice and gesture', It is also mentioned that the narrator does not just read a story loudly, but $\mathrm{h}(\mathrm{s}) \mathrm{e}$ also presents it in such a way that the audience is encouraged to participate creating images using its imagination. It can be argued that it is a living 


\section{$3^{\text {rd }}$ International Conference On Advanced Research in EDUCATION}

experience, where the narrator and the audience coexist and travel together in a fantastic journey of words and images.

Storytelling pre-existed before even books appeared. Images on cave murals provide evidence of the need of people to tell everyday stories or express even their fantasy. Stories narrated are based on the experiences of the people themselves, comprise a product of their imagination or are based on traditions (Simmons, 2006). According to Brecht the narrative is the soul of the drama (Brecht\&Willett, 1964), hence listeners and narrators participate in a shared experience that transfer them from the past to the future through stories and myths passed down from generation to generation (Gersie \& King, 1992).

Zippes (1995) thinks that a fairytale could be sexist, racist or abusive with children in some way. A classic tale is a good start for children since they are most probably familiar with its story. Also, Chesner (1991) argues that a teacher as a storyteller has to change her/his voice, use props and gestures in order to make the story interesting for the children. Stories and fairy tales can be very useful for students, since through them students can cultivate their imagination (Gallas, 1994). This comprises one of the most important principles of drama and theatre education (Neelands, 2011-2012, Warwick Handout). Additionally, knowledge of oneself and others is cultivated as well as empathy, as individuals learn about characters and live their experiences (Mello, 2001). Stories and fairy tales introduce children to a world of fantasy that contains elements of real life and present the occasion which can lead to creativity that no one can reach unless they have a prior experience or knowledge since "no one can create in $\alpha$ vacuum or out of it" (Guilford, 1950, p. 448).

Freire (2000) argued that students, provided with the appropriate material by the teachers, could read a text critically, comment upon characters involved as well as their actions. Thus, children's thinking through the stories and the use of Drama is transformed from passive to critical, which is something that will follow them throughout the rest of their academic and social life.

\section{Methodology}

On the basis of the theoretical framework discussed and analysed above, an intervention programme was designed and implemented based on the tools of Dramatic Art in education with the dominance of storytelling strategy. The experimental method (Cohen, \& Manion, 1994) with pre-test and post-test evaluation was chosen as the appropriate method by the researchers. The experimental method is performed when the researcher wishes to identify cause-and-effect relationships between defined variables (Williamson \& Johanson, 2018). The intervention programme was implemented over a period of three months in a population of 400 students, aged 8-10 years drawn from various primary schools in Greece.

\subsection{Aim and research question}

The aim of the present study has been to investigate whether an innovative intervention programme based on drama education techniques and specifically the storytelling tool, could enhance the five critical thinking skills of primary school students. In this regard, the main research question of the study has been phrased as follows: 


\section{$3^{\text {rd }}$ International Conference On Advanced Research in EDUCATION}

Can an innovative intervention program based on the tools of drama education and specifically of storytelling, contribute in the development of the critical thinking skills of primary school students?

As far as the research hypothesis is concerned, on the basis of the above review of the relevant literature this can be phrased as follows: Drama education can contribute to the development of primary school students' critical thinking skills.

\subsection{Preparatory stage of research}

During the preparatory stage of the research, after thoroughly studying the principles governing drama education, the definitions of critical thinking, and identifying the five critical thinking skills that would be evaluated (Ennis, 1993), the independent and dependent variables were specified.

The five skills of critical thinking, abstract and inductive thinking, observation, reliability and problem solving, were defined as dependent variables, while the innovative interventional programme of drama education was defined as the independent variable.

Subsequently, through the application of simple random sampling approach (Cochran, 1977) the 8 primary schools were identified, in two large regions of Greece. A sample of 400 students aged 8-10 was selected in the same way. The 200 students were selected to be the experimental group while the remaining 200 formed the control group.

After the sample was determined, 12 interventions were designed based on the techniques of Dramatic Art in education. The storytelling tool was widely used, as well as various other theatrical techniques such as role-playing games, improvisations, corridor of consciousness, investigative chair, frozen images.

The structure of each intervention did not differ from the rest. It started with motor exercises, games of acquaintance and trust, continued with the telling of a story where theatrical techniques were inserted and closed with a discussion and reflection of what happened. The aim of these innovative interventions was to develop students' critical ability through playful activities and dilemmas.

For the design of the interventions, the age of the sample, the place of implementation, the interests of the students of this age were assessed and their safety was secured since the research part of the present study was carried out and completed in the midst of the pandemic of covid-19.

The multimodal approach was followed. Research being carried out following this approach is supported with valid and complete findings (Bell, 2010). The research instruments chosen and used include: a) a 24-item questionnaire, designed to assess the cultivation of the five critical thinking skills and was based on the questionnaire of Ennis (1993) as well as the theory of Starkey (2010), b) the participatory observation and c) the research diary kept by the researchers throughout the investigation.

Finally, the intervention programme that was designed was submitted to the Ministry of Education, where it was approved to be implemented in the primary schools of the country. 


\section{$3^{\text {rd }}$ International Conference On Advanced Research in EDUCATION}

\subsection{Main research stage}

During the main research stage, the questionnaire that recorded the cultivation of critical thinking skills was distributed and handed out to all 400 students (to 200 of the experimental group and to 200 of the control group of the 8 primary schools). The completion of filling in the questionnaire lasted 45 minutes which coincides with the duration of one teaching hour as specified by the programme schedule of the selected primary schools.

The introduction of the 12 interventions to the programme taught to the 200 students of the experimental group, took place during the school year 2020-2021 and lasted three months. During this time the researchers kept a diary and recorded the students' reactions. Each intervention took place during the course of Drama Education and lasted 45 minutes. The students of the control group over this period continued to attend their courses according to the requirements of conventional course teaching.

The students of the experimental group, through the dilemmas of the heroes of the stories they heard and the theatrical techniques in which they participated, practiced their abstract and inductive thinking, observation, evaluation of a source of information reliability, identification of problematic situations and respective problem-solving skills.

At the end of the interventions, all 400 students were provided with the same questionnaire that was handed out in the beginning of the research to check whether drama education had contributed in the development of their critical thinking skills.

\subsection{Results}

After the collection of the answers to the questionnaires as well as the data of the participatory observation and the research diaries kept by the researchers, a triangulation of the quantitative and qualitative data was carried out for the extraction of valid and reliable results.

\subsubsection{Results drawn from quantitative research (Survey- Questionnaire)}

After the collection of the results, as mentioned above, the statistical processing of the values of the dependent variables followed, which was carried out using the statistical program SPSS. The researchers considered it necessary to study each dependent variable separately.

The means of the dependent variables were measured on the same scale, at two different points, with the statistical criterion z-normal distribution. The statistical test for normal distribution was performed with the Shapiro-Wilk test and the distribution of the population from which the sample has been drawn is approximately normal. Cronbach's alpha reliability index was used to calculate the reliability of the diagnostic instrument. During the analysis of the results, based on the values observed before and after the intervention, Cronbach's alpha values were calculated for each of the five skills. The procedure was performed for both the control group and the experimental group. Table 1 presents the mean (M) and standard deviation (SD) values for all of the five variables as they evolved in the experimental group. 


\section{$3^{\text {rd }}$ International Conference On Advanced Research in EDUCATION}

Table 1. Measurement values of the variables of subtraction-induction-reliability-observation-detection and problem-solving skills of the experimental group

\begin{tabular}{|c|c|c|c|c|c|c|c|c|}
\hline & \multicolumn{2}{|c|}{ Before } & \multicolumn{2}{|c|}{ After } & \multicolumn{4}{|c|}{ Result } \\
\hline & $\begin{array}{c}\text { Mean } \\
\text { estima } \\
\text { te }\end{array}$ & $\begin{array}{c}\text { standard } \\
\text { deviatio } \\
n\end{array}$ & $\begin{array}{c}\text { mean } \\
\text { estimat } \\
\mathrm{e}\end{array}$ & $\begin{array}{c}\text { standard } \\
\text { deviatio } \\
n\end{array}$ & $\begin{array}{c}\text { mean } \\
\text { estimat } \\
\mathrm{e}\end{array}$ & $\begin{array}{c}\text { standard } \\
\text { deviatio } \\
n\end{array}$ & $\begin{array}{c}\mathrm{z} \\
\text { valu } \\
\mathrm{e}\end{array}$ & $\begin{array}{c}\mathrm{P}(>\mid \mathrm{z} \\
\mid)\end{array}$ \\
\hline Subtraction & 1.96 & 0.20 & 1.60 & 0.50 & 0.36 & 0.49 & $\begin{array}{c}3.67 \\
4\end{array}$ & $\begin{array}{c}<0.0 \\
01\end{array}$ \\
\hline Induction & 1.80 & 1.19 & 2.64 & 1.19 & -0.84 & 1.46 & $\begin{array}{c}2.87 \\
1 \\
\end{array}$ & 0.002 \\
\hline Reliability & 4.36 & 1.15 & 3.52 & 1.47 & 0.84 & 1.84 & $\begin{array}{c}2.28 \\
1\end{array}$ & 0.011 \\
\hline Observation & 2.32 & 0.48 & 2.28 & 1.10 & 0.04 & 1.24 & $\begin{array}{c}0.16 \\
1\end{array}$ & 0.436 \\
\hline Problem solving & 0.92 & 0.64 & 2.24 & 1.23 & -1.32 & 1.37 & $\begin{array}{c}4.79 \\
7 \\
\end{array}$ & $\begin{array}{c}<0.0 \\
01 \\
\end{array}$ \\
\hline $\begin{array}{l}\text { Experimental } \\
\text { group }\end{array}$ & 200 & udents & & & & & & \\
\hline
\end{tabular}

The results for all of the five skills, subtraction, induction, reliability, observation, detection and problem solving presented in Table 1. above, have a positive statistical significance (confidence interval <0.001). For the observation skill $\mathrm{P}(>|\mathrm{z}|)$ is high enough equal to 0.436 . The probability that they did not develop the observation skill is $0.436 \times 100=43.6 \%$. The results can be interpreted that after the completion of the intervention programme, all the skills except from the observation skills of the students improved (the reason is provided in the discussion section below). Table 2. shows the mean (M) and standard deviation (SD) for all of the five skills in the control group.

Table 2. Measurement values of the variables of subtraction-induction-reliability-observation-detection and troubleshooting skills of the control group

\begin{tabular}{|c|c|c|c|c|c|c|c|c|}
\hline & \multicolumn{2}{|c|}{ Before } & After & \multicolumn{4}{|c|}{ Result } & \\
\hline & $\begin{array}{c}\text { mean } \\
\text { estimate }\end{array}$ & $\begin{array}{l}\text { standard } \\
\text { deviation }\end{array}$ & $\begin{array}{c}\text { mean } \\
\text { estimate }\end{array}$ & $\begin{array}{l}\text { standard } \\
\text { deviation }\end{array}$ & $\begin{array}{c}\text { mean } \\
\text { estimate }\end{array}$ & $\begin{array}{l}\text { standard } \\
\text { deviation }\end{array}$ & $\begin{array}{c}\mathrm{Z} \\
\text { value }\end{array}$ & $\mathrm{P}(>|\mathrm{z}|)$ \\
\hline Subtraction & 1.24 & 0.66 & 1.04 & 1.04 & 0.20 & 1.08 & 0.926 & 0.177 \\
\hline Induction & 2.52 & 1.32 & 2.28 & 2.28 & 0.24 & 1.54 & 0.782 & 0.217 \\
\hline Reliability & 3.84 & 1.17 & 3.40 & 3.40 & 0.44 & 1.68 & 1.305 & 0.096 \\
\hline Observation & 1.84 & 1.28 & 1.96 & 1.96 & -0.12 & 1.81 & 0. & 0.370 \\
\hline $\begin{array}{c}\text { Problem } \\
\text { solving }\end{array}$ & 1.76 & 1.23 & 1.96 & 1.96 & -0.20 & 1.22 & $\begin{array}{c}- \\
0.816\end{array}$ & 0.207 \\
\hline $\begin{array}{l}\text { Control } \\
\text { group }\end{array}$ & 200 & dents & & & & & & \\
\hline
\end{tabular}

The results of the control group presented in Table 2. do not exhibit any statistical significance.

In conclusion, the statistical analysis of the investigated data showed that the research hypothesis was confirmed. The students of the experimental group, who attended the 12 interventions that were based on the principles of educational drama, strengthened the four skills of their critical thinking in contrast to the findings of the control group. Therefore, the quantitative research revealed that the answer to the main research question is that educational drama through its innovative practices, can influence and improve the critical thinking of primary school children. 


\section{$3^{\text {rd }}$ International Conference On Advanced Research in EDUCATION}

\subsubsection{Results drawn from qualitative research}

At the end of the interventions, the data of the participatory observation and the research diaries was collected, processed and evaluated. During the interventions, the students' reactions, behaviours and opinions expressed were recorded in the researchers' diaries. A main characteristic of the interventions was that they included several dilemmas that caused the students to think of carrying out more complex processes.

The twelve interventions were based on stories drawn either from the textbook anthology or from well-known stories aiming at the introduction of children in a new world, guiding them to think differently through drama games and role-playing.

A representative example included in the story that was read to the students, involved a villager who was trying to take advantage and deceive a snake that was helping him, and despite this behaviour of the villager the snake kept coming back to him in order to offer assistance. To the question "What would you do if you were in the place of the snake?" one student replied that he would like to discuss the problem with the snake itself and find a solution to the villager's bad behaviour together.

Moreover, when checking the reliability of information sources was requested, students would express their opinion through phrases such as: "I heard this on the TV, but we do not know if it is true" which was heard many times as a statement made by the students.

Then, children were given the opportunity to practice their critical thinking by looking for solutions through alternative ways, such as still images. Moreover, students were asked to watch and observe all the details of the story, draw their own conclusions and express their own opinions. In addition, inductive thinking was practiced through storytelling and participants draw conclusions about the heroes and their character as well as their role in the plot of each story. In their effort to answer the question: "What should the hero have done differently to achieve the desired result?", students practiced their abstract thinking and came to different conclusions by discussing them with each other.

In conclusion, the results of the qualitative research tools coincided with the results of the quantitative data. On this basis, the experimental research carried out in the context of the present study revealed that practicing the theatrical techniques of drama education and storytelling in particular can develop the five skills of primary school students' critical thinking.

\subsubsection{Discussion}

The completion of present study was not free of limitations. The main limitation faced by the researchers was that some interventions such as these related to the observation skills and the respective activities had to be made online due to the widespread pandemic of covid-19 and the restrictions imposed by the Ministry of Education to ensure the safety of students. This explains the low rate of development of students' observation skills which in turn confirms the research hypothesis. Nevertheless, this did not stop children from being creative. The interventions on the researchers' part were designed with care but also imagination so that the students, even in these special 


\section{$3^{\text {rd }}$ International Conference On Advanced Research in EDUCATION}

conditions, could adapt and respond in order to cultivate their critical thinking skills the development of which had been set as a goal of the study.

A secondary limitation encountered was that all the interventions that were implemented with physical interaction were carried out in the students' classrooms and not in a special area since the schools could not provide any. In addition, there were restrictions on students' movements in the area that resulted in reduced students' expressiveness.

However, we observe according to the results of quantitative and qualitative data, that drama education even when delivered under special and difficult conditions can cultivate the skills of critical thinking. Anderson (2012) argues that drama classroom is like a laboratory which is not similar to the space where the other subjects are delivered.

\section{Conclusion}

The experimental research carried out on a sample of 400 students confirmed the initial hypothesis and answered positively to the study's main research question. The 12 intervention workshops that took place over a period of three months confirmed that the critical thinking of primary school students can be developed through theatrical techniques and especially the storytelling proposed by drama education.

Drama education is an innovative educational proposal which proves that through a playful process, students can cultivate skills important for their lives. The experience of educational drama can affect children's judgment and how they perceive the world around them. It can offer crucial knowledge to them as well as the ability to expand their frame of reference (De la Roche, 1993). Educational drama through role-plays, improvisations, storytelling drawn from the experiences of team members can improve critical thinking skills.

\section{Acknowledgment}

This research is co-financed by Greece and the European Union (European Social Fund- ESF) through the Operational Programme "Human Resources Development, Education and Lifelong Learning 2014-2020", in the context of the project "Empowerement of Critical Thinking skills through Drama in Education in primary's schools students" (MIS 5048964).

The authors declare no competing interests.

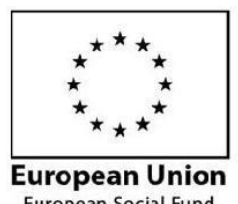

European Social Fund
Operational Programme Human Resources Development, Education and Lifelong Learning

Co-financed by Greece and the European Union
=EएПA 焉 $2014-2020$ 


\section{$3^{\text {rd }}$ International Conference On Advanced Research in EDUCATION}

11-14 March, $2021 \quad$ Oxford - United Kingdom

\section{References}

Anderson, M. (2012). MasterClass in drama education: transforming, teaching and learning. Continuum.

Bell, J. (2010). Doing your research project. A guide for first-time researchers in education, health and social science (5th Ed). Open University Press.

Bolton, G. (2007). A History of Drama Education: A Search for Substance. In L. Bresler (Ed), International Handbook of Research in Arts Education. Springer International Handbook of Research in Arts Education. (16) https://doi.org/10.1007/978-1-4020-3052-9_4

Brecht, B., \& Willett, J. (1964). Brecht on theatre. Methuen Drama.

Chadwick, C. (2014). Teaching kids to think critically: Effective problem solving and better decisions. Rowman \& Littlefield.

Chesner, A. (1998). Creative drama groupwork for people with learning difficulties. Winslow.

Cochran, W. G. (1977). Sampling techniques (3rd Ed). John Wiley and Sons.

Cohen, L., \& Manion, L. (1994). Research Methods in Education. Routledge.

Cook, C. (1917). The play way (1st Ed.). Heinemann.

De la Roche, E. (1993). Drama, Critical Thinking and Social Issues. ERIC Document Reproduction Service ED379172.

Dewey, J. (1910). How We Think. D.C Heath and Company. https://doi.org/10.1037/10903-000

Dewey, J. (1997). How We Think. Dover Publications, Inc.

Dima, A., Kaiafa, E. \& Tsiaras, A. (2020). Evaluation of the Educational Drama as an Innovative Method to be Adopted by Teachers in Order to Enhance Critical Thinking Skills of Students in Primary School. Open Journal for Educational Research, 4(2), 103-116.

Dostal, J. (2014). Theory of problem solving. Procedia - Social and Behavioral Sciences, 174, $2798-2805$.

Doyle, C.(1993). Raising Curtains on Education: Drama as a site for Critical Pedagogy (1st Ed.). Bergin \& Garvey.

Eales-Reynolds, L., Judge, B., Jones, P., \& McCreery, E. (2013). Critical thinking skills for education students (2nd Ed). SAGE Publications, Ltd.

Ennis, R. (1993) Critical thinking assessment. Theory Into Practice, 32(3), 179186, https://doi.org/10.1080/00405849309543594

Facione, P. A. (1990). Critical Thinking: A Statement of Expert Consensus for Purposes of Educational Assessment and Instruction. The California Academic Press.

Fisher, A. (2001). Critical Thinking: An Introduction. Cambridge University Press. 


\section{$3^{\text {rd }}$ International Conference On Advanced Research in EDUCATION}

Franks, A. (2019, August 28). Drama and Learning. Oxford Research Encyclopedia of Education. Retrieved January 23, 2021, from https://oxfordre.com/education/view/10.1093/acrefore/9780190264093.001.0001/ac refore-9780190264093-e-391

Freire, P. (2000). Pedagogy of the oppressed. Continuum.

Gallagher, K., Rhoades, R., \& Cardweell, N. (2017). Drama in Education and Applied Theatre, from Morality and Socialization to Play and Postcolonialism. Oxford Research Encyclopedias, 1-36. https://doi.org/10.1093/acrefore/9780190264093.013.34

Gallas, K. (1994). The language of learning: How children talk, write, dance draw and sing their understanding of the world. Teachers College Press.

Gersie, A.,\& King, N. (1992). Story making in Education and Therapy (2nd Ed.) Jessica Kingsley Publisher.

Guilford, J. (1950). Creativity. American Psychologist, 5(9), 444-454. https://doi.org/10.1037/h0063487

Hacker, D. (2006). The Bedford handbook (7 th Ed.). Bedford/St. Martins.

Heathcote, D., \& Wagner, B. (1976). Drama as a learning medium. National Education Association.

Hsieh, C., Nickerson, J.K. \& Zenger, T.R. (2007). Opportunity Discovery, Problem Solving and a Theory of the Entrepreneurial Firm. Journal of Management Studies, 44(7), 1255-1277. https://doi.org/10.1111/j.1467-6486.2007.00725.x

Jiang, Y. (2017). A Study on Professional Development of Teachers of English as a Foreign Language in Institutions of Higher Education in Western China. Springer Publication.

Karamustafaoğlu, S. (2011). Improving the Science Process Skills Ability of Science Student Teachers. Eurasian Journal of Physics and Chemistry Education, 3(1), 2638.

Matsagouras, H. G. (2001). Teaching critical thinking in Greece. Journal of Cognitive Education and Psychology, 1(3).

McGregor, D. (2007). Developing Thinking, Developing Learning. Open University Press.

Mello, R. (2001). The Power of Storytelling: How Oral Narrative Influences Children's Relationships in Classrooms. International Journal of Education \& the Arts, 2 (1). http://www.ijea.org/v2n1/

Mreiwed, H.,Carter, M., \& Shabtay, A. (2017). Building classroom community through drama education. $N J, 41(1), 44-57$. https://doi.org/10.1080/14452294.2017.1329680

National Council of Teacher of English. (1992, June). A Position statement from the committee on storytelling. ncte.org https://ncte.org/statement/teachingstorytelling/

O'Neil, C., \& Lambert, A. (1976). Drama Guidelines. Heinmann Educational Books Ltd. 


\section{$3^{\text {rd }}$ International Conference On Advanced Research in EDUCATION}

11-14 March, $2021 \quad$ Oxford - United Kingdom

Padmanabha, C.H. (2018). Critical thinking: Conceptual framework. I-manager's Journal on Educational Psychology, 11 (4), 45-53.

Paul, R. \& Elder, L. (2012). Critical thinking: tools for taking charge of your learning and your life ( $3^{\text {rd }}$ Ed.). Pearson/Prentice Hall.

Rieber, R., \& Robinson, D. (2004). The Essential Vygotsky. Springer US.

Simmons, A. (2006).Notes on The Story Factor Inspiration, Influence, and Persuasion through the Art of Storytelling, Basic Books.

Starkey, L. (2010). Critical thinking skills success in 20 minutes a day. Learning Express.

Sweeney, M. (1936). The drama class as a means of character education. The English Journal, 25(4), 301-305.

Trochim, W.M.K. (2/20). Deduction \& Induction. From https://conjointly.com/kb/deduction-and-induction/

Williamson, K. \& Johanson, G. (2018). Research Methods: Information, Systems, and Contexts (2nd Ed.). Chandos Publishing.

Winship, F. (2009). Educational theatre: A definition. The Southern Speech Journal, 19(4), 317-323. https://doi.org/10.1080/10417945409371327

Winston, J., \& Tandy, M. (2009). Beginning Drama 4-11 (3rd Ed.). Routledge.

Zipes, J. (1995). Creative storytelling. Routledge. 